\title{
Urban Sprawl Impact on The Social Change in West Suburb of Malang City
}

\author{
Satti Wagistina \\ Doctoral Program of Environmental Science \\ Brawijaya University \\ J1. MT Haryono No. 169,65145 \\ Malang, Indonesia \\ Department of Geography \\ Faculty of Social Science \\ Universitas Negeri Malang \\ J1. Semarang No. 5, 65145 \\ Malang, Indonesia \\ Corresponding email: satti.wagistina.fis@um.ac.id \\ Agus Suman \\ Department of Geography \\ Faculty of Social Science \\ Universitas Negeri Malang \\ J1. Semarang No. 5, 65145 \\ Malang, Indonesia \\ Antariksa \\ Department of Economic Science and Development Study Economic and Bussiness Faculty \\ Brawijaya University, Jl. MT Haryono No. 165, 65145 \\ Malang, Indonesia \\ Bagyo Yanuwiadi \\ Department of Biology Faculty of Mathematic and Science \\ Brawijaya University \\ J1. MT Haryono No. 165, 65145 \\ Malang, Indonesia
}

\begin{abstract}
The aim of the study to analyze the impact of urban sprawl on the social change. The method for analysis was thematic method. The data were collected from 100 respondents by means of structured interview. In-depth interview was also employed to those who took role as the stakeholders of the society. The research uncovered that the social change that happened in the west suburban area was due to the occurrence of the change from rural to suburb. In addition, the change happened gradually. The thematic method used for this analysis which found that the social change constituted a transitional zone from rural to urban consisted of four main themes, namely: 1) the structural change of society, 2) the lifestyle change, 3) the socio-culture orientation change, and 4) traditional value and custom change.
\end{abstract}

Keywords-Urban sprawl, social change, suburb area, migrant, local societies

\section{INTRODUCTION}

The lands availability in Malang City continually goes restricted while the usage of lands raises intensively. Besides, the society growth keeps soaring during 2005 to 2019 in which the average amounted to $3.9 \%$. The society's need on the lands has been more despite the fact that the lands' availability in Malang City is not equivalently adjusting the society population. The width of Malang City constitutes $110.06 \mathrm{~km}^{2}$, of which population total signified 890,636 in 2016. Therefore, the population density signifies 8,092 people per $\mathrm{km}^{2}$. This result is not that ideal for certain areas. According to BPS (Statistic Bureau), the ideal population density for an urban area must be 1,000 people per $\mathrm{km} 2$. This refers that the society's urge on the lands will also significantly affect the urge on the urban area. The relatively high population density in addition to the lack of 
support of lands causes the highly expensive lands' price. The high price of the lands is the main consequence of the significant development of Malang City as postulated in the theorems of urban lands (Alonso, 1960; Jager 2003; Capozza et.al. 1989). This condition compels the productive land usage drive, to be specific in the suburb of Malang City. The suburban area, in general, is still functioned as the agricultural land to represent the identity of the rural area. Alluding to the aspect of economic land, the value of the field-agricultural lands is more of low compared to the lands that are functioned for other activities (Rustiadi, 2016). The price gap in suburb area of Malang City causes the massive lands' usage that drives to lands' conversion, from the non-built to the built lands, most parts of which are functioned as residences. Therefore, the majority of the society that has been resided in Malang City rationally prefer the residential area in the suburb which is located nearby their workplaces.

The change process from the non-built lands to the residential areas gradually affects the unplanned lands' usage, randomized pattern, and unsupported by the access of transportation, especially in the suburb of Malang City. The research by Wagistina (2016) reveals that the built land growth during 1995 to 2015 in the west suburb-Malang constitutes 0.329 . This means that there has been a massive land conversion, from field-rice to the residential areas. This massive process of the land usage is familiarly renowned as urban sprawl (Northam, 1975; Harvey et al., 1971; Bourney,1996; Yunus,2002; Bhatta,2010). This sprawl process, in addition to causing a land conversion, in sequence, causes economic, environmental, and social changes (Ardiwijaya et al.2014).

The urban sprawl progressively creates some suburbs - the rural that changes to suburb (Soetomo, 2002). This is because the suburban area constitutes the transitional zone snaking from the rural to the urban (Simon, 2008). The suburban area also signifies a resultant of the activities' expansion from the urban area to the administrative border of it (Woltjer, 2014). By 1995, the area of west suburb of Malang City in 1995 used to be a rural area that gradually expanded to be a suburban area. As a transitional zone, there was a gradual change in the west suburb. In addition, the change basically referred to physical, social, and regionallyeconomic dimensions.

The change from rural to suburban area yields a socioeconomic effect on the suburban society due to the industrial growth (Sari et al, 2007). As the transitional zone, the suburban area tends to cause a land conflict as the consequence of the increase of the economic value of the lands (Lombard, 2015). The population growth because of suburbanization in the suburb will trigger a traffic jam (Soesilowati, 2008). The urban sprawl to the suburb also causes social and spatial segregations among the migrant and local societies (Daskalovaet al.2015). However, this study has a specific theme, which is the impact of urban sprawl that changes the rural area as the transitional zone to the suburb resulting a social change. Thereafter, the main purpose of this paper is to analyze the impact of the urban sprawl to the social change in the west suburb of Malang City. This study of benefit as information in regards to city development, in order to control the development in Malang City.

\section{METHOD}

The definition of urban sprawl, to be precise in this current study, refers to several literatures. The urban sprawl constitutes an expansion from urban to the suburb of which characteristics are lowly dense residential areas, converting the agricultural lands to the residential ones, and unintentionally developing the urban. The foremost indicator of the urban sprawl is the built up land growth in the west suburb of Malang City during 19952015.

\section{A. Study Area}

This study was located in the west suburb of Malang City, considering these several aspects: 1) the rapid growth of the built-up area; 2) the suburbanization and the urban sprawl happening along the main transportation access which connects the primary access to the west suburb of Malang City; 3) the administrative location that borders on two sub-districts, Dau and Wagir.

\section{B. Population and Sample}

Population in this study comprised the society of west suburbMalang City. The number of samples was considered by means of sampling quota constituting 100 respondents. In addition, the respondents were selected by means of purposive sampling considering the prior deliberation of living in the west suburb. The purposive sampling of respondent by means of information from neighbourhood head. The information about the respondents was acquired from the chief of the neighboring community.

\section{Method for Data Analysis}

The method used for the data analysis was thematic method. The thematic method, in this study, was concerned on the respondents' answers after the open and in-depth interviews were employed based on the interview guide that had formerly been settled. By means of this thematic method, the social change themes were yielded based on the formulated questions (Hancock et. al., 2006). The thematic analysis was conducted by measuring the words or phrases, the foci of the identification, in addition to describing the implicit as well as explicit ideas from the key informants as the data that could be addressed as the theme (Guest et al.2012). 


\section{FINDINGS AND DISCUSSION}

\section{A. Structural Change of Society in West Suburb-Malang}

The urban sprawl brought a structural change in the society, going from mechanical society to organic society. The mechanical society referred to those who lived in a rural. By 2000 , west suburb was inseparably related to the rural area of which society's characteristic denoted an intimate social relationship, actively social bonding, as well as strongly emotional bonding. Therefore, it is the mechanical solidarity that was established.

The mechanical solidarity was progressively running up to the end of 1999, when decentralization was officially issued and Batu Regency was still an autonomous region. Point of departure of the development of west suburb occurred in 2000 in spite of the autonomy era of motorizing the regional development and the availability of planned residential areas. The mechanical solidarity ensued because, before 2000 , the west suburban society of Malang was still agrarian. The classical point of view proposed by Emile Durkheim (as cited in Kamanto, 2000) denotes that the mechanical solidarity constitutes an only social development, or familiarly known as a segmental society. The society of west suburb worked hand-in-hand to execute certain jobs. For instance, when there was a family who would like to build a house, in a specific period, the work would be executed cooperatively with the colleagues as well as the neighbors. This meant that what people could do, others could so. The mechanical solidarity is hitherto still of visibility despite the fact that it is no longer as significant as that of happening in 2000. This kind of solidarity is and was still existing in a restricted community, called family.

The social change upon being an organic society has been running since 2000. The physical change of the suburb was due to the establishment of the residential areas in addition to an industry that happened gradually. In line with the growth of the built-land, the migrant began to reside in the planned residential areas. The existence of the migrant directly contributed to resulting the social change. The social change engaging the migrant and native inhabitants gave impact to bring the social relationship. This social relationship would happen gradually and in sequence in terms of changing the structure of the mechanical society to the organic society.

The organic society was characterized from the social relationship that occurred due to the benefit factor and the looseness. After 2000, farmers sold the lands to the residence developers. Local societies whose jobs were farmer altered to another job in an informal sector. The farmers' soft skill was so limited that there was no choice, but working in informal sector. As the consequence, the social change, from agrarian to nonagrarian society, could not be denied to occur. The social interaction that commonly occurred in the rice-field was eliminated. Local societies who resided in the planned area were able to provide the others with jobs in the informal sector. At last, the social relationship was based on the interest and of looseness. Within the organic society, the organic solidarity was created in the west suburb-Malang.

\section{B. The lifestyle Change of The Society Around West Suburb of Malang City}

The spatial transformation from rural to suburb gradually affected the lifestyle change. The lifestyle within this study referred to socio-cultural orientation, from the traditional to modern era. The characteristic change of the residence was the impact of the urban sprawl that brought up the change to the socio-cultural change. The existence of the migrant was also deemed to affect the way of thinking, attitude, and behavior patterns of local societies. It was these three patterns that formed the lifestyle of local societies of west suburb.

The social way of thinking that used to be simple was transformed to be more sophisticated. The more complex way of thinking was exhibited by the family's educational background of local societies which was even better compared to what happened in 2000. Local societies' ways of thinking contributed importantly to determining the prospective destiny. To get suitable job, better education is, in fact, of necessity. The created way of thinking was caused by the social segregation of the migrant and native inhabitants. The social segregation could be identified from the socio-economic background of the migrant that was better than local societies'. The current study uncovered that most of the main jobs (equal to $48 \%$ ) of local societies were in the informal sector. The primary jobs of the migrant were in the formal sector (converted to 58\%); while entrepreneurship was equal to $30 \%$ in total. Most of people residing as the migrant were about $90 \%$ graduating from senior high schools and university; while the new habitans were about $92 \%$ having a lower education. This socio-economic segregation pushed local societies to change the way of thinking from traditionalism to the modernization.

TABLE I. ThE PRIMARY JobS OF MigRANT AND LOCAL SOCIETIES IN Habitans In West Suburb OF MaLANG City

\begin{tabular}{|c|l|c|c|c|c|}
\hline \multirow{2}{*}{ No } & \multirow{2}{*}{$\operatorname{Job}(s)$} & \multicolumn{2}{c|}{ Migrant } & \multicolumn{2}{c|}{ Local Societies } \\
\cline { 3 - 6 } & & Frequency & $\%$ & Frequency & $\%$ \\
& & & & & \\
\hline 1 & Civil Servant & 12 & 24 & 5 & 10 \\
\hline 2 & Private Employee & 17 & 34 & 7 & 14 \\
\hline 3 & Seller & 6 & 12 & 2 & 4 \\
\hline 4 & Labor & 0 & 0 & 24 & 48 \\
\hline 5 & Farmer & 0 & 0 & 8 & 16 \\
\hline 6 & Entrepreneur & 15 & 30 & 4 & 8 \\
\hline
\end{tabular}


TABLE II. The Education Level Of The Migrant AND Local Societies In Habitans In WeSt SubURb OF MALANG City

\begin{tabular}{|c|l|c|c|c|c|}
\hline \multirow{2}{*}{ No } & \multirow{2}{*}{ Education(s) } & \multicolumn{2}{|c|}{ Local Societies } & \multicolumn{2}{c|}{ Migrant } \\
\cline { 3 - 6 } & Frequency & $\%$ & Frequency & $\%$ \\
\hline 1 & $\begin{array}{l}\text { Elementary } \\
\text { School }\end{array}$ & 19 & 38 & 1 & 2 \\
\hline 2 & $\begin{array}{l}\text { Junior High } \\
\text { School }\end{array}$ & 10 & 2 & 4 & 8 \\
\hline 3 & $\begin{array}{l}\text { Senior High } \\
\text { School }\end{array}$ & 19 & 38 & 14 & 28 \\
\hline 4 & University & 2 & 8 & 31 & 62 \\
\hline
\end{tabular}

The attitude pattern of local societies experienced a change, from being exclusive to be open. The regional development, to be specific from rural to suburb, changed the regional and structural patterns. The provided facilities in certain region including road access, drainage, and electricity had been well-developed. The technology, information, communication, and social interaction developments engaging the migrant and local societies yielded a harmonic relationship, making them able to change the social attitude of local societies to be open towards the change. Local societies experienced adaptation and assimilation upon the semiurbanized values in west suburb-Malang. The attitude change towards modernization could be identified from transparency of local societies upon the migrant. Local societies do not hesitate to work as housemaids for the migrant.

The attitude pattern of local societies upon the structurallyregional change to be the suburban area referred to the social adaptation that went rapidly. The regional dynamism in west suburb was equalized by the social adaptation that was wellestablished. The social adaptation was exhibited by the transformation of the secondary to the primary jobs. The farmers selling the lands to the developer mostly altered to the informal sector. The research revealed that as many as $48 \%$ of the respondents changed their profession from farmer to labor for building construction, housemaid, and industrial labor. Local societies were also adaptive to the dynamism of the suburb. The existences of University of Muhammadiyah Malang and Campus III of State Islamic University of Maliki Ibrahim were positively responded by local societies. Almost local societies as provider residential for students both of campus.

\section{Socio-Cultural Orientation Change}

The socio-cultural orientation change referred to the change that happened in social and cultural values. The urban sprawl caused a density increase in the residences. The new residents referred to the migrant that had socio-cultural background. The existence of the migrant contributed to the social heterogeneity along the west suburb-Malang. By 2000, the socio-cultural condition was relatively homogeneous. The social characteristic denoted was youngster culture referring to Malang's culture, namely deles or cekek, the indigenous culture of Malang. It was characterized by the society that was agrarian, open, with the touching of East Java language by means of Malang dialect (Minarto, 2010).

The urban sprawl affected the social change going from traditionalism to the pluralism. The collegial system was no longer implemented holistically; while the social status was no longer considered by the ownership of the lands for farming. Since 2000, the conversion of land for farming to be the residential areas affected the soar of the lands' prices. The farmers preferred choosing to sell the lands and thus the ownership on the lands would gradually decrease in addition to the fact that the farming field was no longer a family asset. The life success was no longer based on how large the lands they possessed, but based on what jobs they were performing beyond the agricultural sector. As a consequence, the capability of continuing the study to the higher level and the asset ownership would be creeping along.

The cultural pattern that had been altered gradually changed from being agrarian to be non-agrarian. The characteristic change on the environment in the rural encouraged local societies to adapt with the non-agrarian culture. When going to plant in the farming field, there was an ancient tradition, called selamatan, which was to invite the family and the neighbors to pray to achieve success in agricultural yields. After the harvesting was over, such tradition was redone in order to thank to God for the harvesting yields. This custom was not run anymore due to the fact that local societies looked for the other jobs under the informal sector.

The non-agrarian culture would be more developed as long as the information, science, communication, and technology were on progress. The harmonic social interaction also strengthened the growth of non-agrarian culture. This cultural change drove local societies far away from the root of their socio-culture. The loss of the socio-culture gave impact to the norms and values that had been invested in the youngster's perspectives.

\section{CONCLUSION AND SUGGESTIONS}

The urban sprawl directly gave impact to the social change. The physical development from rural to the suburb caused the structural change of social and culture. The radical existence of the migrant was accepted by local societies so that there was no socio-cultural conflict found out. The social change that happened within the society residing in west suburb-Malang was not necessarily denoted negativity. The social change gave a positive impact in the form of orientation of socio-cultural values that changed even better. The asset ownership was no longer a means of success measurement. The real success measurement referred to the improvement of the human resource.

Alluding to the findings of this study, the writer suggests that the growth of the built-lands converting the farming lands be controlled. The caused impact is not only referring to the regionally-physical change, but also social change. Some of 
parties that play crucial role in terms of giving the permission to build the residential areas are to evaluate the policy that has been mandated to the developers.

\section{ACKNOWLEDGMENT}

This study is part of a research programme on Urban sprawl impact on spatial transformation and social change in suburb of Malang City. The programme was financed by Ministry of Research,Technology, and Higher Education. The funding scheme is doctoral dissertation aid. I thank Fahri for insightfull deleniation on suburb area.

\section{REFERENCES}

[1] Alonso, William, 1960, "A Theory of The Urban Land Market", Paper and Proceeding of The Regional Science Association, Volume 6, 1960. Page 149-157. ISSN: 1059-1575

[2] Ardiwijaya,Vevin S.; SoemardiaTresna P; Suganda, Emirhadi and Temenggung,Yuswanda A, 2014, "Bandung Urban Sprawl and Idle Land: Spatial EnvironmentalPerspectives", ICESD 2014: February 19-21, Singapore, APCBEE Procedia 10 ( 2014 ) 208 - 213.

[3] Bhatta,B, 2010, "Analysis of Urban Growth and Sprawl from Remote Sensing", 17 Advances in Geographic Information Science, DOI 10.1007/978-3-642-05299-6_2,C_Springer-Verlag Berlin Heidelberg 2010.

[4] Bourney,Larry S, 1996, "Reinventing The Suburbs: Old Myths and New Relaties", Progres in Planning 46,No.3 (1996): 163-184.

[5] Capozza, Dennis R and Helsley, Robert W, 1989, "The Fundamentals of Land Prices and Urban Growth", Journal Of Urban Economics x,295-306 (1989).

[6] Daskalova, Diliana and Slaev, Aleksander D, 2015, Diversity in The Suburbs: Socio-Spatial Segregation and Mix in Post-Socialist Sofia", Habitat International, 50 (2015) 42e50

[7] Guest,Greg., Namey,E.E.,\& Mitchell,M.L, 2012, "Collecting Qualitative Data: A Filed Manual for Applied Research”, Sage.

[8] Hancock, Dawson R dan Bob Algozzine, 2006, "Doing Case Study Research: A Practical Guide for Beginning Researchers", New York, Teachers College Press.

[9] Jager, Johannes, 2003, "Urban Land Rent Theory: A Regulationist Perspective", International Journal of Urban and Regional Research, Volume 27.2 June 2003.

[10] Lombard, Melanie, 2015, "Land Conflict in Peri-Urban Areas: Exploring The Effects of Land Reform on Informal Settlement in Mexico", Urban Studies Journal, October,2015. P 1-21.

[11] Kamanto, 2000, "Pengantar Sosiologi”, Lembaga Penerbit FE UI, Jakarta

[12] Minarto, Soerjo Wido, 2010, "Struktur Simbolik Tari Topeng Patih Pada Dramatari Wayang Topeng Malang di Dusun Kendungmonggo", BAHASA DAN SENI, Tahun 38, Nomor 1, Februari 2010.

[13] Rustiadi, Ernan, 2016, "Alih Fungsi Lahan dalam Perspektif Lingkungan Perdesaan", Artikel dimuat di (https://www.researchgate.net/publication/265284147)

[14] Simon,David, 2008, "Urban Environments: Issues on the Pheri-Urban Fringe", The Annual Review of Environment and Resources, 2008, 33:167-85. environ.annualreviews.org. This article's doi:10.1146/annurev.environ.33.021407.093240.

[15] Soekanto, S, 2002, "Sosiologi Suatu Pengantar", Edisi terbaru, Jakarta, Raja Grafindo.

[16] Soetomo,Sugiono, 2002, "Strategi Desain Ruang Suburban Dalam Menopang Pembangunan yang Berkelanjutan: Merajut Ruang yang Beragam dari Pedesaan ke Perkotaan”, Pidato Pengukuhan Guru Besar Pada Fakultas Teknin Universitas Diponegoro, Semarang, 3 Agustus 2002.

[17] Sari, Maulien Khairina dan Winarso, Haryo, 2007, "Transformasi Sosial Ekonomi Masyarakat Peri-Urban di Sekitar Pengembangan Lahan Skala Besar", Kasus Bumi Serpong Damai, Jurnal Perencanaan Wilayah dan Kota, Volume 18 No.1, April 2007, halaman 1-30.
[18] Soesilowati, Etty, 2008, "Dampak Pertumbuhan Ekonomi Kota Semarang Terhadap Kemacetan Lalu Lintas di Wilayah Pinggiran dan Kebijakan yang Ditempuhnya", JEJAK, Volume 1, Nomor 1, September, 2008.

[19] Wagistina,Satti, 2016, "Dampak Perambahan Kota Terhadapa Transformasi Spasial dan Perubahan Sosial di Wilayah Suburban Kota Malang”, Laporan Penelitian Hibah Disertasi Doktor, Ditjen Kementerian Riset,Tekonologi, dan Pendidikan Tinggi.

[20] Woltjer, Johan, 2014, "A Global Review on Peri-Urban Development and Planning. Jurnal Perencanaan Wilayah dan Kota. Vol. 25, no. 1, hlm. 1-16, April 2014. ISSN 0853-9847 @ 2014 SAPPK ITB. 